\title{
The adoption of technologies, management practices, and production systems in U.S. milk production
}

\author{
Jeffrey Gillespie ${ }^{1 *}$, Richard Nehring $^{2}$ and Isaac Sitienei ${ }^{3}$
}

\author{
* Correspondence: jmgille@lsu.edu \\ 1 Department of Agricultural \\ Economics and Agribusiness, \\ Louisiana State University \\ Agricultural Center, Martin D \\ Woodin Hall, Baton Rouge, LA \\ 70803, USA \\ Full list of author information is \\ available at the end of the article
}

\begin{abstract}
Adoption rates of 19 dairy technologies, management practices, and production systems (TMPPS) are estimated for the U.S. for 2005 and 2010 and, in cases where data are available, 1993 and 2000. Logit models are estimated to determine types of farms most likely to use each TMPPS. TMPPS experiencing the greatest increases in adoption have been automatic take-offs, the internet, breeding technologies, and USDA certified organic production; recombinant bovine somatotropin experienced a reduction in usage between 2005 and 2010. Factors influencing TMPPS usage include farm size, tenure, and diversification; farmer age and education; and region of the U.S. where the farm is located.
\end{abstract}

Keywords: Technology adoption; Breeding technology; Computerized technology; Production system

\section{Background}

Over the past two decades, the U.S. dairy industry has experienced significant structural change that has been accompanied by increases in the adoption of productivityinfluencing technologies, management practices, and production systems (TMPPS). A number of factors can be attributed to changes in TMPPS usage by dairy farmers, including the capacity of some TMPPS to allow for realization of benefits associated with economies of size and/or improved efficiency, as well as changing consumer tastes and preferences for milk produced under specific production systems. The research presented in this paper adds to past literature on dairy technology adoption by analyzing the drivers that have influenced the use of TMPPS in the U.S. dairy industry, estimating new 2010 aggregate adoption estimates for these TMPPS, and analyzing the adoption diffusion of these TMPPS over the past two decades.

There have been large changes in numbers of dairy farms, total milk production, and milk production per cow in the U.S. over the past 20-years. From 1991 to 2010, total milk production increased by $30 \%$, the number of farms decreased by $66 \%$, and milk production on a per-cow basis increased by $42 \%$, showing significant changes in the industry structure and productivity over the period. Clearly, average farm size increased along with cow productivity. A major contributor to this structural change has been the adoption of TMPPS that have allowed for greater economies of size and increased cow productivity. 
Farmers generally adopt a TMPPS if it serves to increase farm profit and fits within the farm's resource constraints. In deciding whether to adopt a TMPPS, the farmer must consider whether it would change output quantity, output price, and/or cost of production. For example, use of recombinant bovine somatotropin (rbST) serves to increase milk produced per cow, but in areas where non-rbST premium milk prices are provided, a lower effective price per unit is received for milk produced under the technology. Furthermore, adoption would serve to alter production costs. In addition to the costs and returns associated with a TMPPS, farmers must consider whether adoption can occur given land, labor, capital, and credit constraints. For example, adoption of a pasture-based system may not fit within the farm's resource constraints if insufficient land is available for grazing or the land is in a higher-value use.

A number of studies have addressed factors influencing the adoption of various combinations of TMPPS in dairy production, most using limited dependent variable models to assess factors influencing usage. Table 1 describes each TMPPS and provides a brief summary of previous work for each. The most recent comprehensive study addressing TMPPS usage in U.S. dairy production was Khanal et al. (2010). The present study differs from theirs in several important ways. First, they analyzed 11 TMPPS; we analyze a fuller set, 19. Second, their analysis used mean comparison tests to compare usage on the basis of five farm and farmer demographic drivers, while we use multivariate analysis (logit) to analyze usage with 16 drivers, including farm, farmer demographic, and regional variables. Thus, we were able to fully account for the influence of adoption drivers used in the logit regression models. Third, their analysis focused on adoption drivers in 2000 and 2005 while ours focuses on the more recent 2010 data. Fourth, our analysis uses the full set of USDA Agricultural Resource Management Survey (ARMS) and Farm Costs and Returns Survey (FCRS) data, dairy versions, since 1993 to examine aggregate adoption over a 17 -year period. Though this period is not sufficient to examine full diffusion of most technologies from introduction to equilibrium, it provides insight into TMPPS use patterns over an extensive period of diffusion.

The analysis of technology adoption and its determinants in agriculture has a rich history. In an early classic analysis of the technology adoption process, Griliches (1957) examined the diffusion of hybrid corn in the U.S., showing that technology diffusion followed an S-shaped, logistic curve from introduction to equilibrium. This shape implies that adoption diffusion starts off rather slowly, speeds up, and eventually levels out. He further showed strong influences of region on adoption rates, suggesting that identical adoption diffusion curves do not exist under all conditions. Cochrane (1958) discussed the agricultural treadmill, addressing how early technology adopters generally benefit the most economically, with late adopters being forced to either adopt or exit production. The analysis of technology adoption in agriculture increased throughout the 1960s and 1970s. By 1985, Feder et al. (1985) had reviewed the extensive literature on technology adoption in developing countries, discussing the major adoption drivers. The literature addressing technology adoption in agriculture has expanded since then, with a large body of work conducted on adoption determinants, the extent of which will not be fully discussed here. A substantial amount of this work has dealt with the U.S. dairy industry, much of which is discussed within this paper with respect to each of the TMPPS. 
Table 1 Technologies, management practices, and production systems analyzed in the study TMPPS Description

Computerized and/or Automated Technologies

Computerized feed delivery system

Provides specific feed ration to an individual or group of cows, depending upon cow's lactation phase. Typically used with total mixed ration designed to meet the animal's full nutritional needs.

Computerized milking system

At least compiles computerized milking data from milker, but may also refer to an automatic milking system or fully automated robotic system. Data provided useful for making individual cow decisions (Gillespie et al., 2009a).

On-farm computer to manage Dairy Records

Provides not only convenient way for farmers to keep farm records, but also facilitates analysis of the records.

Accessing the internet for dairy Information

May yield information on prices, input and output markets, and other useful data. Larger dairy farmers more prone to adopt technology and hold off-farm jobs have had greater internet experience (Grisham and Gillespie, 2008).

Automatic take-offs for milking units

Ensure cows are not under- or over-milked (resulting in increased mastitis incidence). Senses end of milk flow, shutting off milking unit vacuum and releasing it from the cow. Results in increased labor productivity and comfort.

Holding pen with an udder Washer Facilitates automatic washing of cow teats prior to cow entering the milking parlor.

Breeding and/or Biological Technologies

Artificial insemination

Involves artificially introducing semen into cow after collection from bull and processing. Introduced in the 1940s. Realized quick diffusion as a means to introduce superior genetics and eliminate transfer of venereal diseases (Foote, 1996), increase economic advantage (Barber, 1983), and avoid the need for farmers to deal with bulls. Khanal and Gillespie (2013) found higher profitability and lower costs with artificial insemination.

Sexed semen

Once collected from the bull, sperm separated into female $X$-bearing and male Y-bearing sperm cells prior to artificially inseminating. Advantage is ability to produce calves of desired sex (DeVries et al., 2008), though lower conception rates have been of concern (Wiegel, 2004)

Embryo transfer

Involves flushing embryos from a donor cow and transferring them to a recipient cow that is usually less valuable.

Recombinant bovine somatotropin

Released for commercial use in 1994 and expected to increase milk yield by about $10 \mathrm{lbs} /$ day. Adoption and effect on farm profitability extensively studied (e.g., McBride et al., 2004; Tauer, 2009;

Gillespie et al., 2010), with most finding no significant impact of use on farm cost and/or profitability. Modest adoption, partly due to negative consumer reactions to its use.

Management Practices

Regular veterinary services

Promotes improved herd health and feed efficiency, with the objective of increasing production efficiency.

Use of a nutritionist to design feed mixes or purchase feed

Improves herd health and efficiency, with objective of increasing production efficiency. May help in curbing excretion of specific nutrients that are of environmental concern.

Keeping individual cow Production Records

Provides information on performance of each animal, assisting farmer in breeding, culling, and other decisions to increase production efficiency.

Forward purchasing of inputs

Involves contracting with an input supplier prior to purchase to ensure steady supply of inputs at a specified price, reducing risk.

Negotiating price discounts

for dairy inputs

Facilitates procurement of lower-cost inputs. Generally more useful for larger operations that can purchase inputs in bulk. 32\% of U.S. farms used forward contracts in 1994, with cash crop farmers using them more extensively than dairy farmers (Mishra and Perry, 1999).

Production systems

Milk cows three or more times per day

Facilitates efficient parlor usage and increased cow productivity. Third milking increases milk production per cow 6\% to 19\% (Amos et al., 1985: DePeters et al., 1985). Additional yield similar across cows regardless of cow productivity (Erdman and Varner, 1995). Reduced reproductive 
Table 1 Technologies, management practices, and production systems analyzed in the study (Continued)

\begin{tabular}{ll}
\hline & efficiency may result as cow spends more time being milked \\
& (Gisi et al., 1986). \\
& Compared to stanchion milking systems, use of a parlor generally reduces \\
Use of a dairy parlor & milking labor costs and is more cost-efficient for larger herds (Tauer 1998). \\
& Various configurations include swing, herringbone, parallel, side opening, \\
& polygon, carousel, flat barn. Cows enter stalls for milking, usually on raised \\
& platforms, and are released after milking. \\
& Refers to extensive use of pasture for cow's forage needs. Provision of \\
& $\geq 50 \%$ of the cow's forage ration from pasture during the grazing \\
& months (Gillespie et al., 2009b). Generally produces less milk per cow, \\
Pasture-based milk production & but at lower cost per cow. Some consumers willing to pay premium \\
& prices for milk from pasture-based operations. No significant differences \\
& found in profitability between pasture-based and similar-scale conventional \\
& milk production (Gillespie et al., 2009b). \\
& Has increased over past decade in response to consumer demand. Requires \\
& use of organically-grown feed and no growth promotants or antibiotics. U.S. \\
organic milk production costs shown to be \$5 - \$8/cwt higher than for & conventional milk (McBride and Greene, 2009). No significant differences \\
production & in technical efficiency found between U.S. organic and non-organic dairy \\
farms (Mayen et al., 2010). & \\
Refers to practice of synchronizing breeding, calving, lactation, and dry \\
seasons in dairy herd. Most often used in pasture-based operations to \\
exploit optimal pasture conditions throughout year, but also other \\
advantages (Turner and Skele, 2007). \\
\hline
\end{tabular}

In this paper, in accordance with Feder et al. (1985), we use the term, "aggregate adoption" to refer to the portion of U.S. producers using each TMPPS. Adoption diffusion, on the other hand, refers to the "process of spread of a new (TMPPS)" (Feder et al., 1985), in our case throughout the U.S.

Technologies, management practices, and production systems in the U.S. dairy production We categorize the major TMPPS used in U.S. dairy production as computerized and/or automated technologies, breeding and/or biological technologies, management practices, and production systems. Each TMPPS analyzed in this study is described and discussed in Table 1. Computerized and/or automated technologies refer to technologies that utilize computer hardware and software to enhance the efficient use of resources and/or provide information to the farmer. These technologies included in our analysis are Computerized Feed Delivery System, Computerized Milking System, On-farm Computer to Manage Dairy Records, Accessing the Internet for Dairy Information, Automatic Take-offs for Milking Units, and Holding Pen with an Udder Washer. Breeding and/or biological technologies refer to biological advances that result in greater reproductive and/or production efficiency. These technologies included in our analysis are Artificial Insemination, Sexed Semen, Embryo Transfer, and rbST.

Management practices refer to methods farmers use to impact productivity, with or without the use of a specific technology. Management practices included in our analysis are Regularly Scheduled Veterinary Services, Use of a Nutritionist to Design Feed Mixes or Purchase Feed, Keeping Individual Cow Production Records, Forward Purchasing of Inputs, and Negotiating Price Discounts for Dairy Inputs. Production systems differ if switching from one to another involves a fundamental change in the way the farm is managed on a daily basis. Production systems included in our analysis are Milk Cows Three or More Times per Day, Use of a Dairy Parlor, Pasture-based Milk Production, Organic Milk Production, and Controlling the Breeding and/or Calving Season. Note 
that use of our selected TMPPS does not necessarily increase production or efficiency. For example, pasture-based systems generally require more land and less variable input per unit of milk relative to conventional systems, while producing less milk per cow. Pruitt et al. (2012) similarly categorized TMPPS for U.S. cow-calf farms, without separating the technologies into subcategories.

\section{Methods}

Similar to the exposition provided by Pruitt et al. (2012), economic theory suggests the farmer maximizes expected utility associated with the adoption of TMPPS as:

$$
\max _{i} E U(\pi \mid \mathrm{m})
$$

where $i \in\{0,1\}$ with 0 indicating non-adoption and 1 indicating adoption. The $E U($. operator indicates expected utility; $\pi$ is profit, where $\pi=R_{i}-C_{i}$ (revenue less cost); and $m$ are farm and farmer characteristics that impact adoption.

The logit model, which assumes a logistic distribution, is a limited dependent variable model that is appropriate for analyzing decisions where there is a yes/no (1-0) outcome, such as whether farmers adopt a TMPPS. Using the logit model (Greene, 2000, p.814).

$$
\operatorname{Prob}(\text { TMPPS }=1 \mid x)=\frac{e^{x^{\prime} \beta}}{1+e^{x^{\prime} \beta}}=\Lambda\left(x^{\prime} \beta\right)
$$

Parameters $\beta$ reflect the impacts of changes in $x$ on the probability of adopting the TMPPS and $\Lambda($.) indicates the logistic cumulative distribution function. Two assumptions in a logit analysis examining TMPPS adoption are that producers are either adopters or non-adopters and that a TMPPS is well-defined. In actuality, in some cases producers may be partial-adopters, for example using rbST on a subset of the animals on the farm. We do not have information on percentages of production on a farm covered by each TMPPS, so our analysis addresses whether the TMPPS was adopted for any portion of the farm's production. For the second assumption, it is recognized that for some TMPPS, i.e. a computerized milking system, a range of technologies may fit under that particular category. Due to data limitations, we cannot further subdivide the category, but analyze whether the producer adopted any TMPPS that falls under that category.

Using the logit model, $\beta$ parameters cannot be directly interpreted other than for sign, thus creating the need for measures that can be used to explain the magnitude of an independent variable's influence over adoption. The marginal effect for a continuous variable using the logit model is calculated as in Greene (2000, p.816):

$$
\frac{\partial E[y \mid x]}{\partial x}=\Lambda\left(\beta^{\prime} \mathbf{x}\right)\left[1-\Lambda\left(\beta^{\prime} \mathbf{x}\right)\right] \beta
$$

Marginal effects for dummy variables are calculated as shown in Greene (2000, p. 817). The McFadden $R^{2}$ is used as an indicator of goodness of fit for the models. Independent variables included in the models consist of farm structure, demographic, and regional variables, as follow. 


\section{Independent variables}

\section{Farm structure variables}

Farm size is measured as the number of cows in the operation, Cows, and the number of Acres on the farm. Cows is the average number of milk cows on the operation during the year, divided by 100 for ease of interpretation of marginal effects. As the number of cows increases, it is expected that adoption of TMPPS with associated size economies, such as computerized feed delivery systems, will increase. TMPPS that have been considered to be scale-neutral, such as rbST, have also been found to be more extensively used by larger-scale producers (McBride et al., 2004). Acres is a farm size measure that considers the extent of the land base. Acres is defined as total acres operated, including both owned and leased land, less farmland leased to others, divided by 100 for ease of interpretation of marginal effects.

The portion of farmland owned by the operator, Owned, allows for consideration of the impacts of land tenancy on TMPPS usage. Feder et al. (1985) discuss differential impacts of land tenancy on TMPPS usage, depending on the nature of the TMPPS. TMPPS that require substantial labor and investments in real estate assets (i.e., building improvements) would be expected to have lower usage by renters. Specialization, (Value of Production from Dairy) $\div$ (Value of Total Farm Production), is expected to positively impact the use of TMPPS that reduce risk and/or require greater management. Greater specialization (lower diversification) generally exposes producers to more risk, increasing the attractiveness of TMPPS such as forward pricing.

Variables Organic Milk Production and Pasture-based Milk Production Systems differ in resource usage and, in some cases, output than their "conventional" counterparts, thus their inclusion as independent variables. The expected impact of these systems on adoption varies by TMPPS. For instance, since rbST is prohibited for USDA certified organic dairies and the marginal value product of its use would unlikely exceed the marginal factor cost for pasture-based production, expected signs for these systems would be negative for rbST. Observation suggests that USDA certified organic and pasture-based systems tend to be less technology-intensive in general. On the other hand, use of controlled breeding seasons would be expected to increase with either of these systems and good record-keeping is required for USDA certified organic production.

\section{Farmer demographic variables}

Two farmer demographic variables are included, farmer Age (the farmer's age divided by 10 for ease of interpretation of marginal effects) and whether the farmer holds a four-year College degree. Older farmers have generally been lower users of TMPPS for which they are unlikely to realize a full stream of benefits prior to retirement, or which change their management requirements, such as rbST (McBride et al., 2004). Farmers with more education are expected to be greater users of advanced TMPPS, as found by McBride et al. (2004) and Ward et al. (2008).

\section{Regions}

Nine U.S. production regions are included: West (Arizona-AZ, Colorado-CO, Idaho-ID, New Mexico-NM), Pacific (California-CA, Oregon-OR, Washington-WA), Southeast (Florida-FL, Georgia-GA), Corn Belt (Illinois-IL, Indiana-IN, Iowa-IA, Missouri-MO, 
Ohio-OH), Northern Plains (Kansas-KS), Appalachia (Kentucky-KY, Tennessee-TN, Virginia-VA), Northeast (Maine-ME, New York-NY, Pennsylvania-PA, Vermont-VT), Lake States (Michigan-MI, Minnesota-MN, Wisconsin-WI), and Southern Plains (Texas-TX). These regions differ in dairy industry structure, with the Northeast and Lake States traditionally being the largest dairy regions and the West and Pacific regions experiencing more recent growth. The base region in our models is the Lake States.

\section{Comparing 2005 and 2010 aggregate adoption rates}

Aggregate adoption rates of 19 TMPPS for 2005 and 2010 are compared using pair-wise 2-tailed $t$-tests utilizing the delete-a-group jackknife estimation procedure. The delete-a-group jackknife estimation procedure is used because the ARMS data are collected via a complex survey design with both an area and list frame, rather than a model-based random sample most commonly used for statistical analysis. Dubman (2000) explains how to estimate $t$-tests utilizing this procedure with ARMS data. These tests allow for determination of whether there were significant differences in aggregate adoption rates in 2005 versus 2010 and, thus, whether significant adoption diffusion occurred over the 5-year period for each TMPPS. For 12 of the TMPPS, Khanal et al. (2010) conducted similar analysis for 2000 and 2005. We included their aggregate adoption rates in our graphical analysis in order to present an extended perspective of diffusion. Additional aggregate adoption estimates are made for 1993 and 2000 in cases where data are available, allowing for further investigation of diffusion (to be discussed in greater detail in the next section). In addition to reporting percentages of farms using TMPPS, we also examine percentages of the total milk quantity produced by farmers using each of the TMPPS in 2005 and 2010.

\section{Data}

Data for analyses conducted in this study are primarily from the 2005 and 2010 ARMS, dairy version, conducted by the USDA National Agricultural Statistics Service (NASS) and Economic Research Service (ERS). The ARMS is conducted annually to collect economic information on U.S. farms. Every year, enterprises are selected for more in-depth surveying so that enterprise cost of production, input usage, and production systems can be estimated. The dairy enterprise was surveyed in detail in 1993 (FCRS), 2000, 2005, and 2010 (ARMS). Logit TMPPS adoption models used only 2010 data while aggregate adoption rates were estimated using all available years. We tried pooling 2005 and 2010 data for the logit analyses in a manner similar to Gillespie et al. (2010), but were not able to satisfy the likelihood ratio index poolability test as discussed in Pesaran et al. (1999). We found that interaction terms would be required for the discrete variable indicating year with all other independent variables. The implication was that independent variables had differential effects on the dependent variable, depending upon year. This resulted in multicollinearity, convergence problems in some cases, and minimal additional insight, leading us to use only 2010 data for the logit analyses. To ensure that only commercial operations were surveyed, the operation must have milked at least 10 cows at any time during the year. States covered include those listed above in the Regions subsection; KS and CO were surveyed in 2010 only. The 
ARMS collects information on costs and returns at both whole-farm and dairy enterprise levels, TMPPS usage, and farm and household characteristics.

Sample farms for ARMS are selected from a list maintained by NASS. Using stratified sampling, each farm represents other "like" farms in the population. The dataset contains expansion factors (weights) to allow for extrapolation to the U.S. dairy population of the states where the survey was conducted. These states represent $90 \%$ of the U.S. dairy farm population of farms with 10 or more cows. Data were collected consistently in both 2005 and 2010 (hand enumeration using a complex sampling scheme and broad national coverage), so results from both years can be compared. The 2005 (2010) data include 1,814 (1,915) observations, respectively. For several TMPPS, adoption estimates may be made from the 2000 ARMS dairy survey and the 1993 Farm Costs and Returns Survey (FCRS), both of which were conducted using similar methods and, thus, are comparable to the 2005 and 2010 ARMS. The 2000 ARMS dairy survey included 870 observations from the same states as those in the 2005 ARMS with the exception of ME and OR. The 1993 dairy FCRS included 695 observations. These data do not link the same farms; each year's data is a separate cross-section representing the dairy farm population for that year. For several TMPPS, particularly those in the Computerized and/or Automated Technologies category, it is acknowledged that advances have been made over the past two decades; for example, up-to-date computerized milking systems may look different from those installed in 1993. Thus, interpretation of results for those TMPPS must be made with that realization.

Consistent with Dubman (2000), the delete-a-group jackknife procedure with 30 replicates is used for deriving statistical estimates. For more information as to why this procedure is used to estimate standard errors using the ARMS data derived from a complex survey design, see the report by the National Research Council, Panel to Review USDA's Agricultural Resource Management Survey (2008).

\section{Results and discussion}

\section{Computerized and/or automated technologies}

Aggregate adoption rates for computerized and/or automated technologies are shown in Figure 1. In 2010, computerized feed delivery systems were used by $8.7 \%$ of farmers compared with $7.1 \%$ in 2005, but the difference was not statistically significant (Table 2). This is compared with estimated usage rates of $8.1 \%$ in 2000 (Khanal et al., 2010) and 6.3\% in 1993 (Short, 2000), showing rather tepid diffusion response over the 19932010 period. The percentage of milk produced by farms using computerized feed delivery systems increased from $28.2 \%$ in 2005 to $37.7 \%$ in 2010 (Table 2). For 2010, an additional 100 cows or 100 acres increased usage by 0.7 or 0.3 percentage points, respectively (Table 3). A farmer owning $100 \%$ versus $0 \%$ of his or her land decreased usage by 2.9 percentage points. Increasing the percentage of farm returns from dairy by $1 \%$ increased usage by 0.12 percentage points. Two of the regional variables were significant: Southeastern and Southern Plains producers were less likely to have adopted than Lake States farmers. Overall, while percentages of farmers using computerized feed delivery systems changed little over the past two decades, the percentage of milk produced by farms using this technology increased, explained by increasing numbers of larger-scale farms using it, as supported by our results. Though significance of regions 


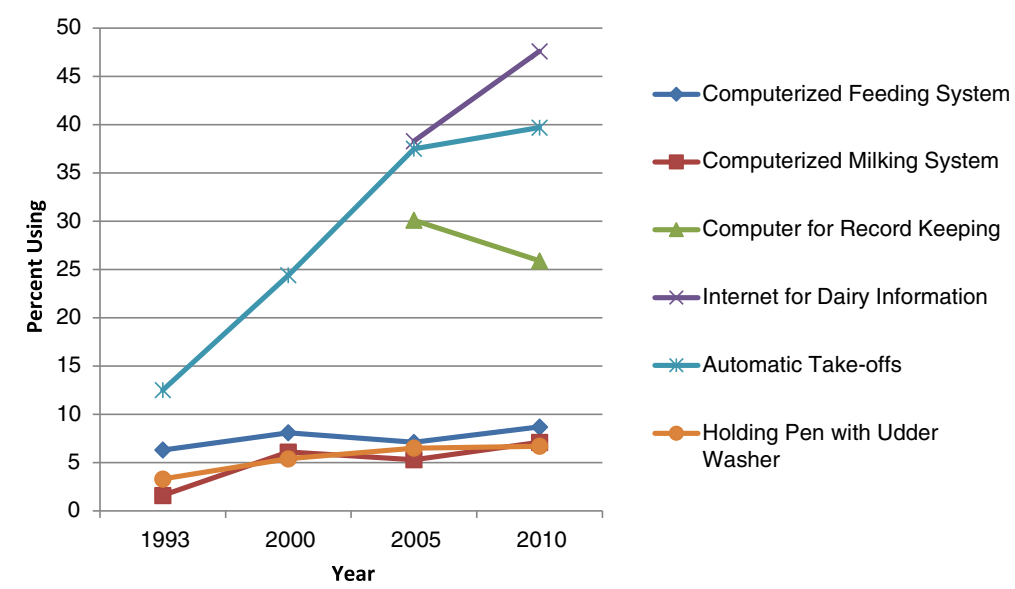

Figure 1 Percentage of U.S. Dairy Farms Using Computerized and/or Automated Technologies.

Source: USDA ARMS and FCRS Dairy Surveys.

is found for most TMPPS and shown in Table 3, in the interest of space, these results are not discussed further in the text.

The aggregate adoption rate for computerized milking systems increased from 5.3\% in 2005 to $7.1 \%$ in 2010. These adoption rates are compared with the estimated aggregate adoption rates of 6.1\% in 2000 (Khanal et al., 2010) and 1.6\% in 1993 (Short, 2000), showing limited diffusion after 2000 . The percentage of milk produced by farms using computerized milking systems was $22.8 \%$ and $24.2 \%$ in 2005 and 2010, respectively. Usage was greater on farms with more acreage, where a higher percentage of the land was owned by the farmer, and that were more heavily specialized in dairy. In 2010, holding a college degree increased usage by 5.6 percentage points. USDA certified organic farmers had usage rates that were 2.3 percentage points lower than those of non-organic farmers. Overall, computerized milking systems experienced modest diffusion over the past decade. Adoption drivers included specialization in dairy and the farmer's education level.

In 2010, the aggregate adoption rate of on-farm computers for record-keeping was $25.9 \%$ of farmers compared with $30.1 \%$ in 2005 , but the difference was not statistically significant. The percentage of milk produced by farmers using an on-farm computer for record-keeping increased from $66.1 \%$ in 2005 to $73.1 \%$ in 2010 . Larger-scale farmers and those holding college degrees were the greater users. Though use of on-farm computers for record-keeping does not appear to have increased from 2005 to 2010, use by larger-scale, more highly-educated producers producing greater percentages of the milk in 2010 suggests greater diffusion in the near future.

The percentage of farms using the internet for collecting dairy information increased from $38.2 \%$ in 2005 to $47.6 \%$ in 2010 . The percentage of milk produced by farmers using the internet for dairy information increased from $63.6 \%$ in 2005 to $79.9 \%$ in 2010 . In 2010, large-scale, specialized, and educated farmers were the greater users. Considering (1) larger farms run by more highly educated farmers are increasing in number, and (2) internet usage is generally diffusing throughout the general population, significant future diffusion is expected.

In 2010, the aggregate adoption rate for automatic take-offs for milking units was $39.7 \%$ of farmers, compared with $37.5 \%$ in 2005 , but the difference was not statistically 
Table 2 Adoption rates of technologies, management practices, and production systems (TMPPS) on U.S. dairy farms

\begin{tabular}{|c|c|c|c|c|}
\hline $\begin{array}{l}\text { Technology, Management } \\
\text { Practice, or Production } \\
\text { System }\end{array}$ & $\begin{array}{l}\text { \% of Farms } \\
\text { Adopting } \\
2005\end{array}$ & $\begin{array}{l}\text { \% of Farms } \\
\text { Adopting } \\
2010\end{array}$ & $\begin{array}{l}\% \text { of Milk Produced } \\
\text { Covered by TMPPS } \\
2005\end{array}$ & $\begin{array}{l}\% \text { of Milk Produced } \\
\text { Covered by TMPPS } \\
2010\end{array}$ \\
\hline \multicolumn{5}{|l|}{$\begin{array}{l}\text { Computerized and/or } \\
\text { Automated Technologies }\end{array}$} \\
\hline $\begin{array}{l}\text { Computerized Feed Delivery } \\
\text { System }\end{array}$ & 7.1 & 8.7 & $28.2^{c}$ & $37.7^{d}$ \\
\hline $\begin{array}{l}\text { Computerized } \\
\text { Milking System }\end{array}$ & $5.3^{\mathrm{a}}$ & $7.1^{b}$ & 22.8 & 24.2 \\
\hline $\begin{array}{l}\text { On-farm Computer } \\
\text { for Records }\end{array}$ & 25.9 & 30.1 & $66.1^{c}$ & $73.1^{d}$ \\
\hline $\begin{array}{l}\text { Internet for Dairy } \\
\text { Information }\end{array}$ & $38.2^{\mathrm{a}}$ & $47.6^{b}$ & $63.6^{c}$ & $79.9^{d}$ \\
\hline $\begin{array}{l}\text { Automatic Take-offs } \\
\text { for Milking Units }\end{array}$ & 37.5 & 39.7 & 72.9 & 77.0 \\
\hline $\begin{array}{l}\text { Holding Pen with an } \\
\text { Udder Washer }\end{array}$ & 6.5 & 6.7 & 31.4 & 30.7 \\
\hline \multicolumn{5}{|l|}{$\begin{array}{l}\text { Breeding and/or Biological } \\
\text { Technologies }\end{array}$} \\
\hline Artificial Insemination & 81.5 & 80.1 & $88.9^{c}$ & $92.2^{d}$ \\
\hline $\begin{array}{l}\text { Embryo Transfer } \\
\text { and/or Sexed Semen }\end{array}$ & $10.4^{\mathrm{a}}$ & $17.8^{\mathrm{b}}$ & $15.7^{c}$ & $24.3^{d}$ \\
\hline $\begin{array}{l}\text { Recombinant Bovine } \\
\text { Somatotropin }\end{array}$ & $16.6^{\mathrm{a}}$ & $8.5^{b}$ & $40.0^{c}$ & $16.6^{d}$ \\
\hline \multicolumn{5}{|l|}{ Management Practices } \\
\hline $\begin{array}{l}\text { Regularly Scheduled } \\
\text { Veterinary Services }\end{array}$ & 68.4 & 65.8 & 87.5 & 90.1 \\
\hline $\begin{array}{l}\text { Nutritionist to Design } \\
\text { Feed Mixes }\end{array}$ & 71.6 & 72.6 & 87.8 & 90.0 \\
\hline $\begin{array}{l}\text { Individual Cow Production } \\
\text { Records }\end{array}$ & 60.6 & 63.6 & 81.6 & 84.9 \\
\hline $\begin{array}{l}\text { Forward Purchasing } \\
\text { of Inputs }\end{array}$ & 19.4 & 21.9 & $44.2^{c}$ & $53.1^{d}$ \\
\hline $\begin{array}{l}\text { Negotiated Price Discounts } \\
\text { for Inputs }\end{array}$ & 34.5 & 36.2 & $60.0^{c}$ & $71.2^{d}$ \\
\hline \multicolumn{5}{|l|}{ Production Systems } \\
\hline $\begin{array}{l}\text { Milk Cows } \geq 3 \text { Times per } \\
\text { Day }\end{array}$ & 7.0 & 9.4 & $30.4^{c}$ & $41.8^{d}$ \\
\hline Dairy Parlor & 49.9 & 53.0 & $83.9^{c}$ & $89.3^{d}$ \\
\hline $\begin{array}{l}\text { Pasture-based Milk } \\
\text { Production }\end{array}$ & 18.3 & 20.0 & 6.8 & 6.6 \\
\hline $\begin{array}{l}\text { USDA Certified Organic Milk } \\
\text { Production }\end{array}$ & 1.6 & 8.6 & $0.7^{c}$ & $3.3^{d}$ \\
\hline $\begin{array}{l}\text { Controlled Breeding and/or } \\
\text { Calving Season }\end{array}$ & 25.3 & 24.8 & 24.2 & 20.9 \\
\hline
\end{tabular}

Superscripts ${ }^{a}$ and ${ }^{b}$ indicate that the estimates differ significantly at $P<0.10$. Likewise, superscripts ${ }^{c}$ and ${ }^{d}$ indicate that the estimates differ significantly at $P<0.10$.

significant. This is compared with estimated aggregate adoption rates of $24.4 \%$ in 2000 (Khanal et al., 2010) (which differed from the 2005 estimated at $P \leq 0.10$ ) and $12.5 \%$ in 1993 (Short, 2000). The percentage of milk produced by farms using automatic takeoffs was $72.9 \%$ and $77.0 \%$ in 2005 and 2010 , respectively. It appears that significant diffusion of the technology occurred up to 2005, with little additional diffusion thereafter. 
Table 3 Logit results of farmer adoption of computerized/automated technology, 2010 (Standard errors in parenthesis)

\begin{tabular}{|c|c|c|c|c|c|c|c|}
\hline \multirow[t]{2}{*}{ Variable } & \multirow[t]{2}{*}{ Units } & \multicolumn{2}{|c|}{ Computerized Feed Delivery System } & \multicolumn{2}{|c|}{ Computerized Milking System } & \multicolumn{2}{|c|}{ Computer to Manage Dairy Records } \\
\hline & & $\beta$ & Marg Effect & $\beta$ & Marg Effect & $\beta$ & Marg Effect \\
\hline Constant & & $-4.8220^{* * *}(0.8249)$ & & $-5.6313^{* * *}(0.9065)$ & & $-2.7211 * * *(0.6024)$ & \\
\hline \multicolumn{8}{|l|}{ Farm Structure } \\
\hline Cows & No./100 & $0.1220^{* * *}(0.0336)$ & $0.0074^{* * *}(0.0020)$ & $0.0214(0.0195)$ & $0.0010(0.0010)$ & $0.4062^{* * *}(0.1406)$ & $0.0892^{* * *}(0.0330)$ \\
\hline Acres & No./100 & $0.0515^{* *}(0.0225)$ & $0.0031^{* *}(0.0010)$ & $0.0791^{* * *}(0.0261)$ & $0.0038^{* * *}(0.0010)$ & $0.1081^{* * *}(0.0334)$ & $0.0237^{* * *}(0.0070)$ \\
\hline Owned & Portion & $-0.4698 *(0.2717)$ & $-0.0285^{*}(0.0162)$ & $0.2866^{* * *}(0.1052)$ & $0.0138^{* * *}(0.0050)$ & $0.1438(0.1046)$ & $0.0316(0.0231)$ \\
\hline Specialized & Portion & $1.9100^{* *}(0.7621)$ & $0.1161^{* *}(0.0477)$ & $2.0391 * *(0.8850)$ & $0.0983^{* *}(0.0425)$ & $0.7340(0.6151)$ & $0.1612(0.1334)$ \\
\hline Organic & $0-1$ & $-0.9541^{* *}(0.3986)$ & $-0.0419^{* * *}(0.0154)$ & $-0.5936^{*}(0.3557)$ & $-0.0231 *(0.0131)$ & $0.0266(0.2031)$ & $0.0059(0.0449)$ \\
\hline Pasture-based & $0-1$ & $-0.0877(0.5212)$ & $-0.0052(0.0301)$ & $-0.3445(0.5208)$ & $-0.0152(0.0201)$ & $-0.2756(0.2593)$ & $-0.0587(0.0527)$ \\
\hline \multicolumn{8}{|l|}{ Farmer Demographics } \\
\hline Age & Yrs./10 & 0.1025 (0.1009) & $0.0062(0.0062)$ & 0.1017 (0.1078) & $0.0049(0.0051)$ & $0.0002(0.0684)$ & $0.0000(0.0150)$ \\
\hline College & $0-1$ & $0.5915^{*}(0.3127)$ & $0.0440(0.0278)$ & $0.8527^{* * *}(0.2893)$ & $0.0559 * *(0.0239)$ & $1.0507^{* * *}(0.2400)$ & $0.2506^{* * *}(0.0580)$ \\
\hline \multicolumn{8}{|l|}{ Regions } \\
\hline West & $0-1$ & $0.4910(0.4646)$ & $0.0367(0.0408)$ & $0.0486(0.4873)$ & $0.0024(0.0244)$ & $0.7398^{*}(0.3949)$ & $0.1769^{*}(0.0975)$ \\
\hline Pacific & $0-1$ & $0.3543(0.4289)$ & $0.0247(0.0334)$ & $0.9872^{* *}(0.3992)$ & $0.0715^{*}(0.0391)$ & $0.3691(0.4413)$ & $-0.0587(0.0527)$ \\
\hline Southeast & $0-1$ & $-0.9249^{*}(0.5238)$ & $-0.0385^{* *}(0.0161)$ & $-3.6464(2.2622)$ & $-0.0513^{* * *}(0.0088)$ & $0.1809(0.3427)$ & $0.0409^{*}(0.0789)$ \\
\hline Corn Belt & $0-1$ & 0.3359 (0.3528) & $0.0225(0.0250)$ & $-0.0159(0.3860)$ & $-0.0008(0.0185)$ & $0.3226(0.2174)$ & $0.0732(0.0501)$ \\
\hline Northern Plains & $0-1$ & $-0.0263(0.5652)$ & $-0.0016(0.0336)$ & $-0.6097(0.7224)$ & $-0.0227(0.0209)$ & $0.3226(0.2174)$ & $-0.0277(0.0849)$ \\
\hline Appalachia & $0-1$ & $-0.1633(0.3950)$ & $-0.0093(0.0215)$ & $-0.0257(0.3921)$ & $-0.0012(0.0186)$ & $-0.2235(0.2494)$ & $-0.0472(0.0511)$ \\
\hline Northeast & $0-1$ & $-0.1040(0.4136)$ & $-0.0062(0.0241)$ & $0.0795(0.4258)$ & $0.0039(0.0212)$ & $-0.0914(0.2640)$ & $-0.0199(0.0571)$ \\
\hline Southern Plains & $0-1$ & $-2.0439^{* *}(1.0421)$ & $-0.0586^{* * *}(0.0137)$ & $-3.6757(3.0604)$ & & $-0.6904(0.4545)$ & $-0.1317^{*}(0.0754)$ \\
\hline
\end{tabular}

Diagnostics

Pseudo R-square

0.1511

0.1266

0.1989 
Table 3 Logit results of farmer adoption of computerized/automated technology, 2010 (Standard errors in parenthesis) (Continued)

\begin{tabular}{|c|c|c|c|c|c|c|c|}
\hline \multirow[t]{2}{*}{ Variable } & \multirow[t]{2}{*}{ Units } & \multicolumn{2}{|c|}{ Computerized Feed Delivery System } & \multicolumn{2}{|c|}{ Computerized Milking System } & \multicolumn{2}{|c|}{ Computer to Manage Dairy Records } \\
\hline & & $\beta$ & Marg Effect & $\beta$ & Marg Effect & $\beta$ & Marg Effect \\
\hline Constant & & $-1.3024^{* * *}(0.5003)$ & & $-1.8703^{* * *}(0.5522)$ & & $-4.4040^{* * *}(0.9720)$ & \\
\hline \multicolumn{8}{|l|}{ Farm Structure } \\
\hline Cows & No./100 & $0.2420^{* *}(0.0998)$ & $0.0605^{* *}(0.0250)$ & $0.3545^{*}(0.1933)$ & $0.0877^{*}(0.0490)$ & $0.0369^{*}(0.0199)$ & $0.0012^{*}(0.0007)$ \\
\hline Acres & No./100 & $0.0820^{* * *}(0.0293)$ & $0.0205^{* * *}(0.0070)$ & $0.1654^{* * *}(0.0421)$ & $0.0409^{* * *}(0.0100)$ & $0.0090(0.0174)$ & $0.0002(0.0010)$ \\
\hline Owned & Portion & $0.0285(0.1061)$ & $0.0071(0.0265)$ & $0.1133(0.1227)$ & $0.0280(0.0304)$ & $0.0779(0.1115)$ & $0.0025(0.0035)$ \\
\hline Specialized & Portion & $1.0941^{* *}(0.4581)$ & $0.2733^{* *}(0.1145)$ & $1.1199^{* *}(0.5113)$ & $0.2769^{* *}(0.1250)$ & $-0.5187(0.6899)$ & $-0.0168(0.0227)$ \\
\hline Organic & $0-1$ & $0.0297(0.1730)$ & $0.0074(0.0432)$ & $-0.6630^{* * *}(0.2012)$ & $-0.1552^{* * *}(0.0439)$ & $-0.6928(0.4412)$ & $-0.0174^{*}(0.0096)$ \\
\hline Pasture-based & $0-1$ & $-0.3330(0.2134)$ & $-0.0830(0.0528)$ & $-0.7728^{* * *}(0.2555)$ & $-0.1821^{* * *}(0.0547)$ & $-0.9543^{*}(0.5126)$ & $-0.0243^{* *}(0.0098)$ \\
\hline \multicolumn{8}{|l|}{ Farmer Demographics } \\
\hline Age & Yrs./10 & $-0.0318(0.0701)$ & $-0.0079(0.0175)$ & $-0.0911(0.0686)$ & $-0.0225(0.0170)$ & $0.2504^{* * *}(0.0951)$ & $0.0810^{* *}(0.0350)$ \\
\hline College & $0-1$ & $1.5028^{* * *}(0.2834)$ & $0.3286^{* * *}(0.0485)$ & $0.8154^{* * *}(0.2822)$ & $0.2006^{* * *}(0.0666)$ & $0.1055(0.2457)$ & $0.0035(0.0085)$ \\
\hline \multicolumn{8}{|l|}{ Regions } \\
\hline West & $0-1$ & $0.1956(0.3883)$ & $0.0486(0.0957)$ & $-1.2902^{* *}(0.6198)$ & $-0.2677^{* * *}(0.1018)$ & $1.2892^{* *}(0.5237)$ & $0.0766^{*}(0.0460)$ \\
\hline Pacific & $0-1$ & $-0.0166(0.3635)$ & $-0.0042(0.0908)$ & $1.2490^{* * *}(0.4616)$ & $0.2944^{* * *}(0.0972)$ & $3.6362^{* * *}(0.4186)$ & $0.4907^{* * *}(0.0799)$ \\
\hline Southeast & $0-1$ & $-0.4735(0.3227)$ & $-0.1170(0.0779)$ & $-1.5584^{* * *}(0.5061)$ & $-0.3041^{* * *}(0.0749)$ & $2.3456^{* * *}(0.4211)$ & $0.2279 * * *(0.0668)$ \\
\hline Corn Belt & $0-1$ & $-0.3144(0.2014)$ & $-0.0784(0.0500)$ & $-0.3053(0.2074)$ & $-0.0744(0.0500)$ & $-0.2714(0.5588)$ & $-0.0081(0.0158)$ \\
\hline Northern Plains & $0-1$ & $-0.1517(0.4114)$ & $-0.0379(0.1027)$ & $0.9535^{* *}(0.4754)$ & $0.2304^{* *}(0.1046)$ & $0.4631(0.8462)$ & $0.0186(0.0408)$ \\
\hline Appalachia & $0-1$ & $-0.7061^{* * *}(0.2290)$ & $-0.1719^{* * *}(0.0531)$ & $0.5523^{* *}(0.2214)$ & $0.1372^{* *}(0.0541)$ & $-0.0985(0.5255)$ & $-0.0031(0.0159)$ \\
\hline Northeast & $0-1$ & $-0.6250^{* * *}(0.2307)$ & $-0.1548^{* * *}(0.0560)$ & $-0.2459(0.2386)$ & $-0.0603(0.0579)$ & $0.0964(0.5536)$ & $0.0032(0.0186)$ \\
\hline Southern Plains & $0-1$ & $-0.6308(0.4073)$ & $-0.1542(0.0950)$ & $-1.6702^{* * *}(0.5661)$ & $-0.3204^{* * *}(0.0789)$ & $1.7811^{* * *}(0.5201)$ & $0.1327^{* *}(0.0624)$ \\
\hline \multicolumn{8}{|l|}{ Diagnostics } \\
\hline Pseudo R-square & & 0.1223 & & 0.1916 & & 0.3086 & \\
\hline
\end{tabular}


In 2010, large-scale, specialized, and educated farmers exhibited higher probability of using the technology. Furthermore, USDA certified organic or pasture-based operations had lower usage rates of 15.5 and 18.2 percentage points, respectively. Though diffusion was relatively stagnant between 2005 and 2010, increases in farm size and farmer education suggest modest diffusion in the near future.

In 2010, the aggregate adoption rate of holding pens with udder washers was $6.7 \%$ of farmers, compared with $6.5 \%$ in 2005 , but the difference was not statistically significant. This is compared with estimated aggregate adoption of 5.4\% in 2000 (Khanal et al., 2010) and 3.3\% in 1993 (Short, 2000). The percentage of milk produced by farms using holding pens with udder washers was 31.4\% and 30.7\% in 2005 and 2010, respectively. In 2010, farmers with more cows were greater users and an additional 10 years of the farmer's age increased usage by 0.8 percentage points. USDA certified organic and pasture-based operations were lower users of this technology. Though diffusion of this technology has stagnated in recent years, increases in farm size and farmer education suggest modest diffusion in coming years.

\section{Breeding and/or biological technologies}

Aggregate adoption rates for breeding and/or biological technologies are shown in Figure 2 and logit results are shown in Table 4. In 2010, the aggregate adoption rate of artificial insemination was $80.1 \%$ of farmers, compared with $81.5 \%$ in 2005 , but the difference was not statistically significant. Khanal et al. (2010) showed that in 2000, 64.3\% of farmers used, as stated in the 2000 ARMS dairy survey, "genetic selection and breeding programs (embryo transplants, artificial insemination)." Since embryo transplants would rarely be used without artificial insemination, it is probable that all of these farms used artificial insemination, making this a reasonable estimate of the percentages of farms using the technology. Given that the 2000 and 2005 usage differed at $P \leq 0.10$, it appears that significant adoption diffusion occurred prior to 2005, but not thereafter. The percentage of milk produced by farms using artificial insemination increased from $88.9 \%$ in 2005 to $92.2 \%$ in 2010 . Greater users of the technology in 2010 were largescale, specialized, and educated farmers. On the other hand, operating a USDA certified organic or pasture-based operation reduced usage. Artificial insemination adoption may be nearing an equilibrium point since $90 \%$ of the milk produced is now covered by this technology.

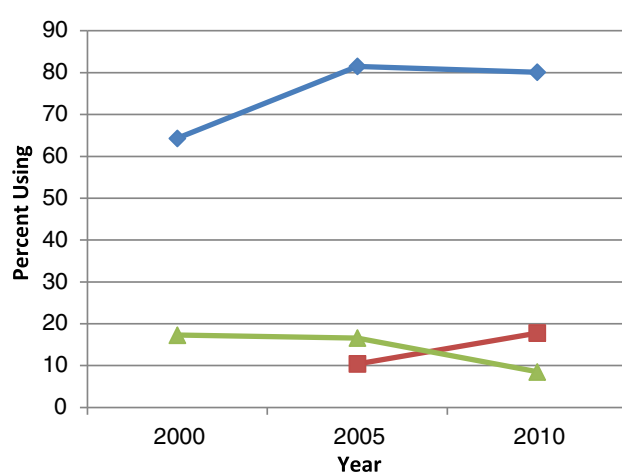

$\sim$ Artificial Insemination (2000 estimate for "genetic selection and breeding programs")

- Embryo Transfer / Sexed Semen

Recombinant Bovine Somatotropin

USDA ARMS and FCRS Dairy Surveys. 
In 2010, the aggregate adoption rate of embryo transfer and/or sexed semen was $17.8 \%$ of farmers, compared with $10.4 \%$ in 2005 , statistically different at $P \leq 0.05$. The percentage of milk produced by farms using embryo transfer and/or sexed semen technology increased from $15.7 \%$ to $24.3 \%$ from 2005 to 2010, respectively. In 2010, largescale, young, and educated farmers were greater users of this technology, while USDA certified organic farmers were lower users. Strong increases are attributed primarily to the diffusion of sexed semen, with additional diffusion expected as farms become larger and more highly educated farmers enter the industry.

In 2010, the aggregate adoption rate of rbST was $8.5 \%$ of farmers compared with $16.6 \%$ in 2005 , statistically different at $P \leq 0.01$. This is compared with an estimated aggregate adoption of 17.3\% in 2000 (Khanal et al., 2010) and shows significant decline in the percentage of farms using rbST. This reduction is likely due to consumer concerns regarding rbST and resultant premiums for milk produced without the use of rbST. Past economic studies that have not shown increased profitability with rbST adoption also partially explain declining usage. Furthermore, to get the desired production response with rbST, greater management of feed inputs is needed. The percentage of milk produced by farms using rbST decreased from $40.0 \%$ in 2005 to $16.6 \%$ in 2010. For 2010, greater ownership of land increased rbST usage.

\section{Management practices}

Aggregate adoption rates for management practices are shown in Figure 3 and logit results are shown in Table 5 . In 2010, the aggregate adoption rate for regularly scheduled veterinary services was $65.8 \%$ of farmers, compared with $68.4 \%$ in 2005 , but the difference was not statistically significant. The percentages of milk produced by farms using regularly scheduled veterinary services were $87.5 \%$ and $90.1 \%$ in 2005 and 2010 , respectively. In 2010, larger-scale and younger farmers were greater users, while certified organic and pasture-based farms were lower users. Increased numbers of larger-scale farms (greater use) along with increased numbers of certified organic farms (lower use) partially explain stagnant adoption.

In 2010, aggregate adoption of a nutritionist to design feed mixes was $72.6 \%$ of farmers, compared with $71.6 \%$ in 2005 , but the difference was not statistically significant. This is compared with an estimated aggregate adoption rate of $66.9 \%$ in 2000 (Khanal et al., 2010). The percentage of milk produced by farmers using a nutritionist to design feed mixes was $87.8 \%$ and $90.0 \%$ in 2005 and 2010, respectively. In 2010, younger farmers and those who had more cows were greater users, while certified organic and pasture-based farmers had lower usage rates. Modest diffusion over the past decade may be partially explained by the opposing factors of increased farm size and increased certified organic production.

The 2010 aggregate adoption rate of individual cow production records was $63.6 \%$ of farmers compared with $60.6 \%$ in 2005 , but the difference was not statistically significant. The percentage of milk produced by farmers keeping individual cow production records was $81.6 \%$ and $84.9 \%$ in 2005 and 2010, respectively. In 2010, large-scale, specialized, educated, and organic-certified farmers were greater users, while pasturebased farmers were lower users. Though rapid diffusion of this practice is not evident, it is generally considered by dairy farm management professionals to be an important component in increasing productivity. More larger and certified organic farms should result in greater diffusion. 
Table 4 Logit results of dairy farmer adoption of breeding and/or biological technologies, 2010 (Standard errors in parenthesis)

\begin{tabular}{|c|c|c|c|c|c|c|c|}
\hline \multirow[t]{2}{*}{ Variable } & \multirow[t]{2}{*}{ Units } & \multicolumn{2}{|c|}{ Artificial Insemination } & \multicolumn{2}{|c|}{$\begin{array}{l}\text { Embryo Transfer } \\
\text { and/or Sexed Semen }\end{array}$} & \multicolumn{2}{|c|}{ Recombinant Bovine Somatotropin } \\
\hline & & $\beta$ & Marg Effect & $\beta$ & Marg Effect & $\beta$ & Marg Effect \\
\hline Constant & & $0.5505(0.5881)$ & & $-1.1789^{* *}(0.5862)$ & & $-2.1980^{* *}(0.9552)$ & \\
\hline \multicolumn{8}{|l|}{ Farm Structure } \\
\hline Cows & No./100 & $0.0904^{* *}(0.0039)$ & $0.0124(0.0050)$ & $-0.0080(0.0137)$ & $-0.0011(0.0020)$ & $0.0227(0.0156)$ & $0.0014(0.0010)$ \\
\hline Acres & No./100 & $-0.0026(0.0203)$ & $-0.0004(0.0030)$ & $0.0430^{* * *}(0.0150)$ & $0.0058^{* * *}(0.0020)$ & $0.0759^{* * *}(0.0258)$ & $0.0047^{* * *}(0.0020)$ \\
\hline Owned & Portion & $0.0272(0.0947)$ & $0.0037(0.0130)$ & $0.1152(0.1086)$ & $0.0156(0.0146)$ & $0.2500^{* *}(0.1140)$ & $0.0153^{* *}(0.0069)$ \\
\hline Specialized & Portion & $1.3565^{* * *}(0.5033)$ & $0.1857^{* * *}(0.0704)$ & $0.2655(0.4738)$ & $0.0359(0.0642)$ & $0.8526(0.7443)$ & $0.0523(0.0458)$ \\
\hline Organic & $0-1$ & $-1.0418^{* * *}(0.1950)$ & $-0.1848^{* * *}(0.0378)$ & $-1.7048^{* * *}(0.2730)$ & $-0.1428^{* * *}(0.0189)$ & & \\
\hline Pasture-based & $0-1$ & $-0.6382^{* * *}(0.2245)$ & $-0.0990^{* * *}(0.0385)$ & $-0.2700(0.3065)$ & $-0.0345(0.0367)$ & $-0.5205(0.4887)$ & $-0.0280(0.0224)$ \\
\hline \multicolumn{8}{|l|}{ Farmer Demographics } \\
\hline Age & Yrs./10 & $0.0585(0.0842)$ & $0.0080(0.0116)$ & $-0.1524^{*}(0.0834)$ & $-0.0206^{*}(0.0112)$ & $-0.2132(0.1448)$ & $-0.0131(0.0089)$ \\
\hline College & $0-1$ & $0.9075^{* * *}(0.2945)$ & $0.0979^{* * *}(0.0243)$ & $0.7171^{* * *}(0.2473)$ & $0.1156^{* *}(0.0456)$ & $0.3967(0.3398)$ & $0.0278(0.0265)$ \\
\hline \multicolumn{8}{|l|}{ Regions } \\
\hline West & $0-1$ & $-1.3309^{* * *}(0.4031)$ & $-0.2591^{* * *}(0.0948)$ & $-0.5137(0.3592)$ & $-0.0584^{*}(0.0351)$ & $-3.1607^{* * *}(1.2306)$ & $-0.0663^{* * *}(0.0104)$ \\
\hline Pacific & $0-1$ & $-0.2934(0.3836)$ & $-0.0438(0.0618)$ & $0.1479(0.3170)$ & $0.0209(0.0463)$ & $-1.2464^{* *}(0.5305)$ & $-0.0488^{* * *}(0.0142)$ \\
\hline Southeast & $0-1$ & $-2.0875^{* * *}(0.3188)$ & $-0.4461^{* * *}(0.0723)$ & $-0.5125(0.4233)$ & $-0.0581(0.0408)$ & & \\
\hline Corn Belt & $0-1$ & $-0.9362^{* * *}(0.2398)$ & $-0.1550^{* * *}(0.0445)$ & $-0.0845(0.2577)$ & $-0.0112(0.0338)$ & $-1.0171^{* * *}(0.3797)$ & $-0.0481 * * *(0.0152)$ \\
\hline Northern Plains & $0-1$ & $-0.6402(0.4731)$ & $-0.1066(0.0917)$ & $-0.2606(0.4214)$ & $-0.0323(0.0481)$ & $-0.7839(0.5455)$ & $-0.0349^{*}(0.0179)$ \\
\hline Appalachia & $0-1$ & $-1.9202^{* * *}(0.2434)$ & $-0.3981^{* * *}(0.0543)$ & $-0.1872(0.2756)$ & $-0.0239(0.0337)$ & $-2.2961^{* * *}(0.7466)$ & $-0.0647^{* * *}(0.0115)$ \\
\hline Northeast & $0-1$ & $-0.0168(0.2927)$ & $-0.0023(0.0403)$ & $0.0724(0.2900)$ & $0.0099(0.0400)$ & $-0.2535(0.3408)$ & $-0.0148(0.0189)$ \\
\hline Southern Plains & $0-1$ & $-2.5655^{* * *}(0.3651)$ & $-0.5501^{* * *}(0.0733)$ & $-1.7184^{* *}(0.6979)$ & $-0.1319^{* * *}(0.0271)$ & $-2.6556^{*}(1.5891)$ & $-0.0643^{* * *}(0.0126)$ \\
\hline \multicolumn{8}{|l|}{ Diagnostics } \\
\hline Pseudo R-square & & 0.1217 & & 0.0459 & & 0.0892 & \\
\hline
\end{tabular}

Note: ${ }^{*}{ }^{* *}$, and ${ }^{* * *}$ indicate significance at the $\mathrm{P} \leq 0.10, \mathrm{P} \leq 0.05$, and $\mathrm{P} \leq 0.01$ levels, respectively. 


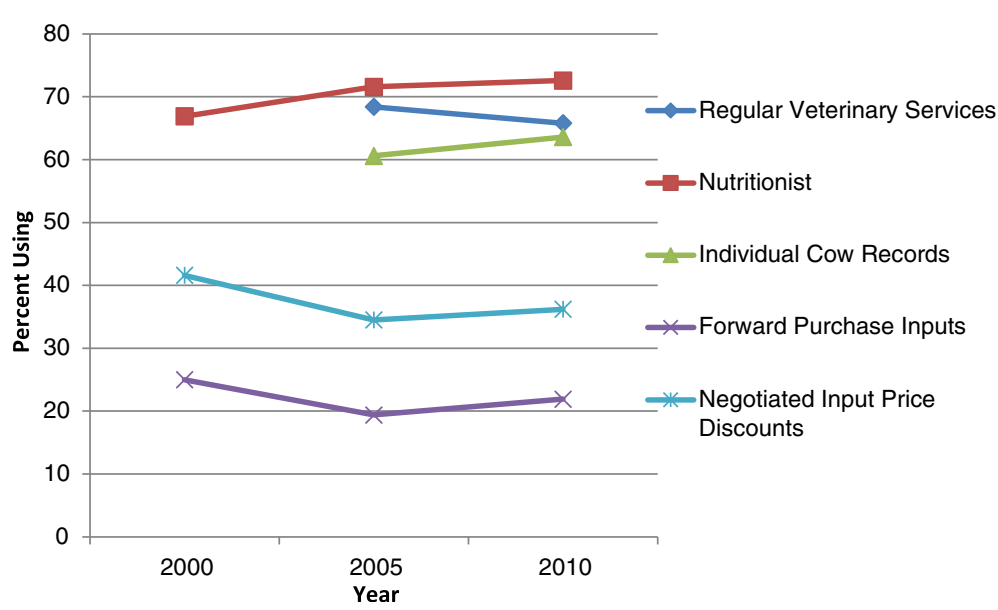

Figure 3 Percentage of Dairy Farms Using Selected Management Practices, U.S. Source: USDA ARMS and FCRS Dairy Surveys.

In $2010,21.9 \%$ of farmers forward-purchased inputs, compared with $19.4 \%$ in 2005 , but the difference was not statistically significant. This is compared with $25.0 \%$ of farmers forward purchasing inputs in 2000. The percentage of milk produced by farmers forward-purchasing inputs increased from $44.2 \%$ in 2005 to $53.1 \%$ in 2010. In 2010, farmers who were larger-scale, younger, educated, and those who owned greater percentages of their farmland were greater users, while certified organic and pasturebased producers were lower users. Though diffusion of this practice is not noticeable on a percentage-of-farms basis, modest diffusion is expected with the entry of largerscale farms with more highly educated producers.

In 2010, 36.2\% of farmers negotiated price discounts for inputs, compared with $34.5 \%$ in 2005 , but the difference was not statistically significant. This is compared with $41.6 \%$ of farmers negotiating price discounts in 2000. The percentage of milk produced by farmers who negotiated for price discounts for inputs increased from $60.0 \%$ in 2005 to $71.2 \%$ in 2010. In 2010, larger-scale, younger, and educated farmers, and those who owned greater percentages of their farmland were greater users, while certified organic farmers were lower users. Implications for further diffusion of this management practice are similar to those for forward purchasing of inputs.

\section{Production systems}

Aggregate adoption rates for production systems are shown in Figure 4 and logit results are shown in Table 6. In 2010, 9.4\% of farmers milked cows at least 3 times a day, compared with $7.0 \%$ in 2005 , but the difference was not statistically significant. This is compared with $3.4 \%$ of farmers milking at least 3 times per day in 2000 (Khanal et al., 2010) (which differed from the 2005 estimate at $P \leq 0.10$ ) and $2.7 \%$ in 1993 . Overall, the percentage of farmers milking cows at least 3 times daily has increased modestly over the past two decades. The percentage of milk produced by farms milking cows at least 3 times per day increased from 30.4\% in 2005 to $41.8 \%$ in 2010. In 2010, larger-scale, specialized, and more educated farmers were greater users, while certified organic and pasture-based farmers were lower users. Though the differences in the percentage of farms using this system was not statistically significant over the period, 2005-2010, it 
Table 5 Logit results for dairy farmer adoption of management practices, 2010 (Standard errors in parenthesis)

\begin{tabular}{|c|c|c|c|c|c|c|c|c|c|c|c|}
\hline \multirow[t]{2}{*}{ Variable } & \multirow[t]{2}{*}{ Units } & \multicolumn{2}{|c|}{$\begin{array}{l}\text { Regular Veterinary } \\
\text { Services }\end{array}$} & \multicolumn{2}{|c|}{$\begin{array}{l}\text { Nutritionist to Design Feed } \\
\text { Mixes/Purchase }\end{array}$} & \multicolumn{2}{|c|}{$\begin{array}{l}\text { Keep Individual Cow } \\
\text { Production Records }\end{array}$} & \multicolumn{2}{|c|}{$\begin{array}{l}\text { Forward Purchasing } \\
\text { of Inputs }\end{array}$} & \multicolumn{2}{|c|}{$\begin{array}{l}\text { Negotiate Price } \\
\text { Discounts for Inputs }\end{array}$} \\
\hline & & $\beta$ & Marg Effect & $\beta$ & Marg Effect & $\beta$ & Marg Effect & $\beta$ & Marg Effect & $\beta$ & Marg Effect \\
\hline Constant & & $\begin{array}{l}0.9779^{*} \\
(0.5619)\end{array}$ & & $\begin{array}{l}2.2682^{* * *} \\
(0.5681)\end{array}$ & & $\begin{array}{l}-0.0730 \\
(0.5371)\end{array}$ & & $\begin{array}{l}-0.9932 \\
(0.6556)\end{array}$ & & $\begin{array}{l}-0.2132 \\
(0.5356)\end{array}$ & \\
\hline \multicolumn{12}{|l|}{ Farm Structure } \\
\hline Cows & No./100 & $\begin{array}{l}0.3171^{* *} \\
(0.1491)\end{array}$ & $\begin{array}{l}0.0638^{* *} \\
(0.0270)\end{array}$ & $\begin{array}{l}0.1747^{*} \\
(0.0907)\end{array}$ & $\begin{array}{l}0.0319^{* *} \\
(0.0160)\end{array}$ & $\begin{array}{l}0.1170 \\
(0.0874)\end{array}$ & $\begin{array}{l}0.0263 \\
(0.0190)\end{array}$ & $\begin{array}{l}0.0969^{* *} \\
(0.0392)\end{array}$ & $\begin{array}{l}0.0152^{* *} \\
(0.0060)\end{array}$ & $\begin{array}{l}0.2356^{* * *} \\
(0.0616)\end{array}$ & $\begin{array}{l}0.0555^{* * *} \\
(0.0150)\end{array}$ \\
\hline Acres & No./100 & $\begin{array}{l}0.0807^{* * *} \\
(0.0290)\end{array}$ & $\begin{array}{l}0.0162^{* * *} \\
(0.0060)\end{array}$ & $\begin{array}{l}0.0245 \\
(0.0230)\end{array}$ & $\begin{array}{l}0.0045 \\
(0.0040)\end{array}$ & $\begin{array}{l}0.0492^{* *} \\
(0.0241)\end{array}$ & $\begin{array}{l}0.0111^{* *} \\
(0.0060)\end{array}$ & $\begin{array}{l}0.0670^{* * *} \\
(0.0218)\end{array}$ & $\begin{array}{l}0.0110^{* * *} \\
(0.0030)\end{array}$ & $\begin{array}{l}0.0769 * * * \\
(0.0235)\end{array}$ & $\begin{array}{l}0.0181^{* * *} \\
(0.0050)\end{array}$ \\
\hline Owned & Portion & $\begin{array}{l}0.1526 \\
(0.0932)\end{array}$ & $\begin{array}{l}0.0307 \\
(0.0187)\end{array}$ & $\begin{array}{l}0.0129 \\
(0.1027)\end{array}$ & $\begin{array}{l}0.0024 \\
(0.0188)\end{array}$ & $\begin{array}{l}0.1515^{*} \\
(0.0906)\end{array}$ & $\begin{array}{l}0.0341^{*} \\
(0.0204)\end{array}$ & $\begin{array}{l}0.1977^{*} \\
(0.1057)\end{array}$ & $\begin{array}{l}0.0310^{*} \\
(0.0167)\end{array}$ & $\begin{array}{l}0.1737^{*} \\
(0.0896)\end{array}$ & $\begin{array}{l}0.0409^{*} \\
(0.0212)\end{array}$ \\
\hline Specialized & Portion & $\begin{array}{l}0.3708 \\
(0.4797)\end{array}$ & $\begin{array}{l}0.0745 \\
(0.0971)\end{array}$ & $\begin{array}{l}0.2184 \\
(0.5011)\end{array}$ & $\begin{array}{l}0.0399 \\
(0.0915)\end{array}$ & $\begin{array}{l}1.0345^{* *} \\
(0.4783)\end{array}$ & $\begin{array}{l}0.2329^{* *} \\
(0.1084)\end{array}$ & $\begin{array}{l}0.1089 \\
(0.5634)\end{array}$ & $\begin{array}{l}0.0171 \\
(0.0883)\end{array}$ & $\begin{array}{l}0.1536 \\
(0.4778)\end{array}$ & $\begin{array}{l}0.0362 \\
(0.1125)\end{array}$ \\
\hline Organic & $0-1$ & $\begin{array}{l}-0.7560^{* * *} \\
(0.1825)\end{array}$ & $\begin{array}{l}-0.1696^{* * *} \\
(0.0437)\end{array}$ & $\begin{array}{l}-0.8361^{* * *} \\
(0.1802)\end{array}$ & $\begin{array}{l}-0.1771^{* * *} \\
(0.0403)\end{array}$ & $\begin{array}{l}0.3477^{*} \\
(0.1894)\end{array}$ & $\begin{array}{l}0.0744^{*} \\
(0.0390)\end{array}$ & $\begin{array}{l}-0.6341^{* * *} \\
(0.2225)\end{array}$ & $\begin{array}{l}-0.0841^{* * *} \\
(0.0265)\end{array}$ & $\begin{array}{l}-0.6024^{* * *} \\
(0.1830)\end{array}$ & $\begin{array}{l}-0.1312^{* * *} \\
(0.0376)\end{array}$ \\
\hline Pasture-based & $0-1$ & $\begin{array}{l}-1.4377^{* * *} \\
(0.2251)\end{array}$ & $\begin{array}{l}-0.3250^{* * *} \\
(0.0546)\end{array}$ & $\begin{array}{l}-1.2251^{* * *} \\
(0.2219)\end{array}$ & $\begin{array}{l}-0.2590^{* * *} \\
(0.0518)\end{array}$ & $\begin{array}{l}-1.0914^{* * *} \\
(0.2155)\end{array}$ & $\begin{array}{l}-0.2599^{* * *} \\
(0.0521)\end{array}$ & $\begin{array}{l}-1.2014^{* * *} \\
(0.2702)\end{array}$ & $\begin{array}{l}-0.1504^{* * *} \\
(0.0262)\end{array}$ & $\begin{array}{l}-0.2873 \\
(0.2310)\end{array}$ & $\begin{array}{l}-0.0661 \\
(0.0516)\end{array}$ \\
\hline \multicolumn{12}{|c|}{ Farmer Demographics } \\
\hline Age & Yrs./10 & $\begin{array}{l}-0.1978^{* * *} \\
(0.0767)\end{array}$ & $\begin{array}{l}-0.0398^{* * *} \\
(0.0154)\end{array}$ & $\begin{array}{l}-0.2680^{* * *} \\
(0.0732)\end{array}$ & $\begin{array}{l}-0.0489^{* * *} \\
(0.0132)\end{array}$ & $\begin{array}{l}-0.0994 \\
(0.0690)\end{array}$ & $\begin{array}{l}-0.0224 \\
(0.0155)\end{array}$ & $\begin{array}{l}-0.1863^{* *} \\
(0.0793)\end{array}$ & $\begin{array}{l}-0.0292^{* *} \\
(0.0126)\end{array}$ & $\begin{array}{l}-0.2208^{* * *} \\
(0.0697)\end{array}$ & $\begin{array}{l}-0.0520^{* * *} \\
(0.0165)\end{array}$ \\
\hline College & $0-1$ & $\begin{array}{l}0.1120 \\
(0.2441)\end{array}$ & $\begin{array}{l}0.0021 \\
(0.0474)\end{array}$ & $\begin{array}{l}0.1344 \\
(0.2611)\end{array}$ & $\begin{array}{l}0.0239 \\
(0.0452)\end{array}$ & $\begin{array}{l}0.6260^{* *} \\
(0.3020)\end{array}$ & $\begin{array}{l}0.1285^{* *} \\
(0.0553)\end{array}$ & $\begin{array}{l}0.9036^{* * *} \\
(0.2394)\end{array}$ & $\begin{array}{l}0.1709^{* * *} \\
(0.0518)\end{array}$ & $\begin{array}{l}0.5234^{* *} \\
(0.2171)\end{array}$ & $\begin{array}{l}0.1275^{* *} \\
(0.0573)\end{array}$ \\
\hline \multicolumn{12}{|l|}{ Regions } \\
\hline West & $0-1$ & $\begin{array}{l}0.1626 \\
(0.3951)\end{array}$ & $\begin{array}{l}0.0315 \\
(0.0746)\end{array}$ & $\begin{array}{l}-0.1990 \\
(0.3567)\end{array}$ & $\begin{array}{l}-0.0381 \\
(0.0707)\end{array}$ & $\begin{array}{l}-0.4782 \\
(0.3339)\end{array}$ & $\begin{array}{l}-0.1139 \\
(0.0824)\end{array}$ & $\begin{array}{l}0.4811 \\
(0.3260)\end{array}$ & $\begin{array}{l}0.0861 \\
(0.0781)\end{array}$ & $\begin{array}{l}-0.0821 \\
(0.3375)\end{array}$ & $\begin{array}{l}-0.0192 \\
(0.0781)\end{array}$ \\
\hline Pacific & $0-1$ & $\begin{array}{l}0.1620 \\
(0.3884)\end{array}$ & $\begin{array}{l}0.0315 \\
(0.0738)\end{array}$ & $\begin{array}{l}-0.5675^{*} \\
(0.3451)\end{array}$ & $\begin{array}{l}-0.1163 \\
(0.0760)\end{array}$ & $\begin{array}{l}0.3482 \\
(0.3762)\end{array}$ & $\begin{array}{l}0.0742 \\
(0.0763)\end{array}$ & $\begin{array}{l}0.2478 \\
(0.3260)\end{array}$ & $\begin{array}{l}0.0415 \\
(0.0576)\end{array}$ & $\begin{array}{l}-0.0817 \\
(0.3208)\end{array}$ & $\begin{array}{l}-0.0191 \\
(0.0743)\end{array}$ \\
\hline
\end{tabular}


Table 5 Logit results for dairy farmer adoption of management practices, 2010 (Standard errors in parenthesis) (Continued)

\begin{tabular}{|c|c|c|c|c|c|c|c|c|c|c|c|}
\hline Southeast & $0-1$ & $\begin{array}{l}-1.3025^{* * *} \\
(0.3561)\end{array}$ & $\begin{array}{l}-0.3077^{* * *} \\
(0.0841)\end{array}$ & $\begin{array}{l}-0.5115 \\
(0.3379)\end{array}$ & $\begin{array}{l}-0.1048 \\
(0.0746)\end{array}$ & $\begin{array}{l}0.2343 \\
(0.3454)\end{array}$ & $\begin{array}{l}0.0507 \\
(0.0721)\end{array}$ & $\begin{array}{l}-0.9940^{* *} \\
(0.3960)\end{array}$ & $\begin{array}{l}-0.1135^{* * *} \\
(0.0327)\end{array}$ & $\begin{array}{l}-0.3641 \\
(0.3387)\end{array}$ & $\begin{array}{l}-0.0815 \\
(0.0718)\end{array}$ \\
\hline Corn Belt & $0-1$ & $\begin{array}{l}-0.1350 \\
(0.2153)\end{array}$ & $\begin{array}{l}-0.0277 \\
(0.0447)\end{array}$ & $\begin{array}{l}-0.2997 \\
(0.2263)\end{array}$ & $\begin{array}{l}-0.0574 \\
(0.0447)\end{array}$ & $\begin{array}{l}-0.1171 \\
(0.2005)\end{array}$ & $\begin{array}{l}-0.0267 \\
(0.0460)\end{array}$ & $\begin{array}{l}0.0895 \\
(0.2222)\end{array}$ & $\begin{array}{l}0.0143 \\
(0.0359)\end{array}$ & $\begin{array}{l}-0.2650 \\
(0.2030)\end{array}$ & $\begin{array}{l}-0.0610 \\
(0.0459)\end{array}$ \\
\hline North Plains & $0-1$ & $\begin{array}{l}-1.0329^{* *} \\
(0.4103)\end{array}$ & $\begin{array}{l}-0.2411^{* *} \\
(0.1026)\end{array}$ & $\begin{array}{l}-0.3279 \\
(0.3884)\end{array}$ & $\begin{array}{l}-0.0647 \\
(0.0815)\end{array}$ & $\begin{array}{l}0.0725 \\
(0.3611)\end{array}$ & $\begin{array}{l}0.0161 \\
(0.0795)\end{array}$ & $\begin{array}{l}0.7164^{*} \\
(0.3945)\end{array}$ & $\begin{array}{l}0.1358 \\
(0.0860)\end{array}$ & $\begin{array}{l}-0.4551 \\
(0.3930)\end{array}$ & $\begin{array}{l}-0.1003 \\
(0.0801)\end{array}$ \\
\hline Appalachia & $0-1$ & $\begin{array}{c}-0.0493 \\
(0.2451)\end{array}$ & $\begin{array}{l}-0.0100 \\
(0.0501)\end{array}$ & $\begin{array}{l}-0.6199^{* *} \\
(0.2457)\end{array}$ & $\begin{array}{l}-0.1285^{* *} \\
(0.0546)\end{array}$ & $\begin{array}{l}-0.0926 \\
(0.2250)\end{array}$ & $\begin{array}{l}-0.0211 \\
(0.0518)\end{array}$ & $\begin{array}{l}0.1971 \\
(0.2412)\end{array}$ & $\begin{array}{l}0.0326 \\
(0.0415)\end{array}$ & $\begin{array}{l}0.1571 \\
(0.2177)\end{array}$ & $\begin{array}{l}0.0376 \\
(0.0526)\end{array}$ \\
\hline Northeast & $0-1$ & $\begin{array}{l}0.2990 \\
(0.2595)\end{array}$ & $\begin{array}{l}0.0583 \\
(0.0488)\end{array}$ & $\begin{array}{l}0.3519 \\
(0.2634)\end{array}$ & $\begin{array}{l}0.0616 \\
(0.0441)\end{array}$ & $\begin{array}{l}-0.0007 \\
(0.2407)\end{array}$ & $\begin{array}{l}-0.0002 \\
(0.0542)\end{array}$ & $\begin{array}{l}-0.1123 \\
(0.2859)\end{array}$ & $\begin{array}{l}-0.0173 \\
(0.0433)\end{array}$ & $\begin{array}{l}-0.1129 \\
(0.2379)\end{array}$ & $\begin{array}{l}-0.0264 \\
(0.0553)\end{array}$ \\
\hline South Plains & $0-1$ & $\begin{array}{l}-1.8523^{* * *} \\
(0.4339)\end{array}$ & $\begin{array}{l}-0.4322^{* * *} \\
(0.0898)\end{array}$ & $\begin{array}{l}-1.1208^{* * *} \\
(0.3858)\end{array}$ & $\begin{array}{l}-0.2503^{* * *} \\
(0.0939)\end{array}$ & $\begin{array}{l}-0.8597^{* *} \\
(0.3474)\end{array}$ & $\begin{array}{l}-0.2087^{* *} \\
(0.0848)\end{array}$ & $\begin{array}{l}-0.2819 \\
(0.4069)\end{array}$ & $\begin{array}{l}-0.0406 \\
(0.0539)\end{array}$ & $\begin{array}{l}-0.4848 \\
(0.3829)\end{array}$ & $\begin{array}{l}-0.1064 \\
(0.0775)\end{array}$ \\
\hline \multicolumn{12}{|l|}{ Diagnostics } \\
\hline Pseudo $R^{2}$ & & 0.1510 & & 0.1141 & & 0.0750 & & 0.1214 & & 0.1038 & \\
\hline
\end{tabular}

Note: ${ }^{*}{ }^{*}$, and ${ }^{* *}$ indicate significance at the $\mathrm{P} \leq 0.10, \mathrm{P} \leq 0.05$, and $\mathrm{P} \leq 0.01$ levels, respectively. 


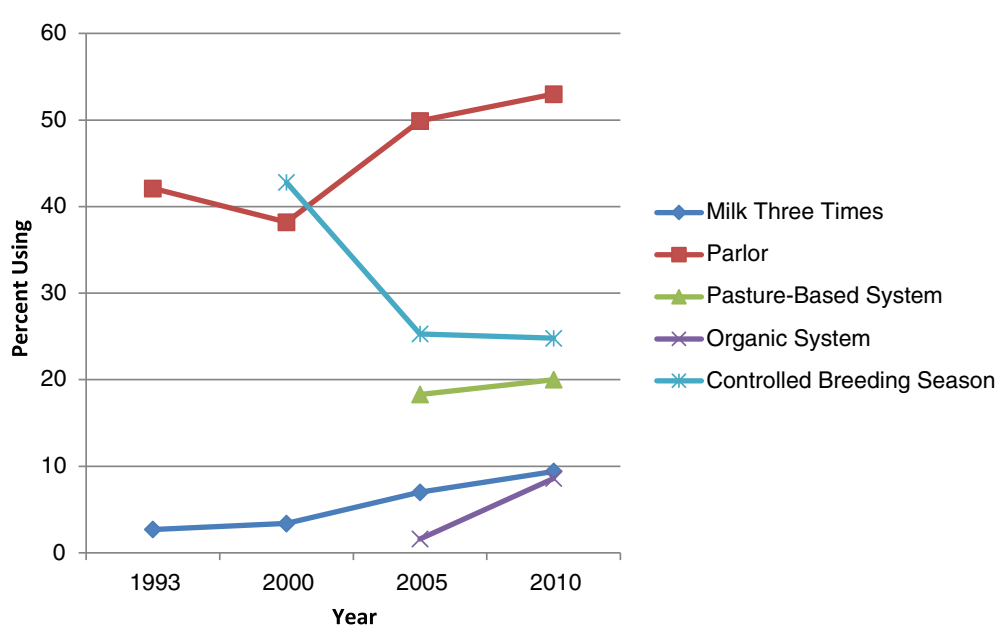

Figure 4 Percentage of Dairy Farms Using Selected Production Systems, U.S. Source: USDA ARMS and FCRS Dairy Surveys.

appears that over the past two decades, steady diffusion has continued with larger-scale, more highly educated producers entering the industry.

In 2010, the aggregate adoption rate of a milking parlor was $53.0 \%$ of farmers, compared with $49.9 \%$ in 2005 , but the difference was not statistically significant. This is compared with an aggregate adoption rate of 38.2\% in 2000 (Khanal et al., 2010) (which differed from the 2005 percentage at $P \leq 0.10$ ) and $42.1 \%$ in 1993 (Short 2000). Overall, the percentage of farms using parlors increased over the past two decades. The percentage of milk produced by farms under a parlor system increased from $83.9 \%$ to 89.3\% from 2005 to 2010, respectively. In 2010, large-scale farmers and those who operated pasture-based operations were greater users. Though diffusion has been modest but steady over the past two decades, the striking increase in adoption with more cows suggests that new, larger entrants will be adopters.

Logit models were not estimated for pasture-based milk production or certified organic milk production because, while they are production systems, they are used as independent variables in the other TMPPS models and are, thus, considered TMPPS adoption drivers. We do, however, examine usage rates for these production systems. In 2010, 20.0\% of operations were pasture-based, compared with $18.3 \%$ in 2005 , but the difference was not statistically significant. Percentages of milk produced by farms under pasture-based systems were $6.8 \%$ and 6.6\% in 2005 and 2010, respectively. Farmers in some markets may receive premiums for pasture-based milk, one of the reasons being that milk produced from pasture-based dairies may have lower somatic cell counts along with higher protein and butterfat components (Horner et al. 2012). Furthermore, USDA certified organic production, which requires cows to have access to pasture, has increased. These factors are likely the major drivers allowing aggregate adoption of pasture-based production to hold steady. Though pasture-based production has not shown significant diffusion in recent years, future consumer demand for milk produced under more "sustainable" systems could be a significant driver influencing its use in coming years.

In $2010,8.6 \%$ of the operations were certified organic, compared with $1.6 \%$ in 2005 , but the difference was not statistically significant, as the coefficients of variation for the estimates were relatively high for both years. The percentage of milk produced by farms using 
Table 6 Logit results for dairy farmer adoption of production systems, 2010 (Standard errors in parenthesis)

\begin{tabular}{|c|c|c|c|c|c|c|c|}
\hline \multirow[t]{2}{*}{ Variable } & \multirow[t]{2}{*}{ Units } & \multicolumn{2}{|c|}{ Milk Cows $\geq 3$ Times/Day } & \multicolumn{2}{|c|}{ Use of a Dairy Parlor } & \multicolumn{2}{|c|}{ Control Breeding and/or Calving Season } \\
\hline & & $\beta$ & Marg Effect & $\beta$ & Marg Effect & $\beta$ & Marg Effect \\
\hline Constant & & $-6.8569^{* * *}(1.3940)$ & & $-2.9046^{* * *}(0.7228)$ & & $1.2252^{* *}(0.5979)$ & \\
\hline \multicolumn{8}{|l|}{ Farm Structure } \\
\hline Cows & No./100 & $0.1168^{* * *}(0.0427)$ & $0.0053^{* *}(0.0020)$ & $3.2069^{* * *}(0.4211)$ & $0.6800^{* * *}(0.0610)$ & $-0.0097(0.0135)$ & $-0.0017(0.0020)$ \\
\hline Acres & No./100 & $0.0853^{* * *}(0.0261)$ & $0.0039^{* * *}(0.0010)$ & $0.0358(0.0516)$ & $0.0076(0.0110)$ & $-0.0229(0.0166)$ & $-0.0041(0.0030)$ \\
\hline Owned & Portion & $0.3359^{* * *}(0.1154)$ & $0.0152^{* * *}(0.0051)$ & $-0.1253(0.0974)$ & $-0.0266(0.0207)$ & $-0.3062^{*}(0.1670)$ & $-0.0545^{*}(0.0296)$ \\
\hline Specialized & Portion & $4.5926^{* * *}(1.3418)$ & $0.2084^{* * *}(0.0617)$ & $-0.7025(0.6383)$ & $-0.1490(0.1336)$ & $-0.2972(0.4909)$ & $-0.0529(0.0873)$ \\
\hline Organic & $0-1$ & $-2.6073^{* * *}(0.9107)$ & $-0.0542^{* * *}(0.0114)$ & $0.1841(0.2108)$ & $0.0378(0.0421)$ & $0.5651^{* * *}(0.1937)$ & $0.1126^{* * *}(0.0400)$ \\
\hline Pasture-based & $0-1$ & $-1.2610(0.7799)$ & $-0.0425^{* *}(0.0170)$ & $0.5428^{* *}(0.2322)$ & $0.1072^{* * *}(0.0418)$ & $0.7396^{* * *}(0.2317)$ & $0.1463^{* * *}(0.0502)$ \\
\hline \multicolumn{8}{|c|}{ Farmer Demographics } \\
\hline Age & Yrs./10 & $0.0159(0.1527)$ & $0.0007(0.0069)$ & $0.0482(0.0987)$ & $0.0102(0.0210)$ & $0.0424(0.0694)$ & $0.0075(0.0123)$ \\
\hline College & $0-1$ & $1.1874^{* * *}(0.2842)$ & $0.0838^{* * *}(0.0277)$ & $0.0248(0.3723)$ & $0.0052(0.0783)$ & $0.2968(0.2374)$ & $0.0560(0.0472)$ \\
\hline \multicolumn{8}{|l|}{ Regions } \\
\hline West & $0-1$ & $0.0407(0.4535)$ & $0.0019(0.0213)$ & & & $0.5220^{*}(0.3079)$ & $0.1048(0.0668)$ \\
\hline Pacific & $0-1$ & $-1.1548^{* *}(0.5672)$ & $-0.0341^{* * *}(0.0119)$ & & & $0.3633(0.2941)$ & $0.0701(0.0601)$ \\
\hline Southeast & $0-1$ & $-2.3947^{* * *}(0.5348)$ & $-0.0442^{* * *}(0.0087)$ & & & $1.6935^{* * *}(0.3116)$ & $0.3884^{* * *}(0.0713)$ \\
\hline Corn Belt & $0-1$ & $-0.8453^{* *}(0.3685)$ & $-0.0306^{* *}(0.0126)$ & $2.0361^{* * *}(0.2759)$ & $0.3186^{* * *}(0.0367)$ & $0.4468^{* *}(0.2277)$ & $0.0855^{*}(0.0450)$ \\
\hline North Plains & $0-1$ & $-0.0042(0.5353)$ & $-0.0002(0.0242)$ & & & $1.3877^{* * *}(0.3852)$ & $0.3141^{* * *}(0.0936)$ \\
\hline Appalachia & $0-1$ & $-0.9534^{* *}(0.3915)$ & $-0.0299^{* * *}(0.0101)$ & $3.2609^{* * *}(0.3809)$ & $0.3231^{* * *}(0.0361)$ & $0.9836^{* * *}(0.2441)$ & $0.2114^{* * *}(0.0561)$ \\
\hline Northeast & $0-1$ & $-0.5939(0.3898)$ & $-0.0242(0.0148)$ & $-0.1933(0.2540)$ & $-0.0415(0.0555)$ & $-0.1774(0.2772)$ & $-0.0309(0.0472)$ \\
\hline South Plains & $0-1$ & $-1.5348^{* *}(0.7694)$ & $-0.0382^{* * *}(0.0115)$ & & & $0.9363^{* * *}(0.3637)$ & $0.2015^{* *}(0.0870)$ \\
\hline \multicolumn{8}{|l|}{ Diagnostics } \\
\hline Pseudo $R^{2}$ & & 0.2374 & & 0.3665 & & 0.0569 & \\
\hline
\end{tabular}


a certified organic system increased from $0.7 \%$ in 2005 to $3.3 \%$ in 2010. Further diffusion of certified organic milk production will likely be driven by consumer demand.

In 2010, 24.8\% of the farmers controlled their breeding and/or calving seasons, compared with $25.3 \%$ in 2005 , but the difference was not statistically significant. This is compared with $42.8 \%$ of farmers controlling breeding seasons in 2000. The percentages of milk produced by farms controlling breeding and/or calving seasons were $24.2 \%$ and $20.9 \%$ in 2005 and 2010, respectively. In 2010, small-scale and certified organic farmers, and those who operated pasture-based systems were greater users. Though use of this system appears to be declining, future usage may depend partially on the usage of pasture-based and certified organic systems.

\section{Adoption relationships among TMPPS}

Previous research has established that adopters of most TMPPS are also adopters of most of the others, with Khanal et al. (2010) and Pruitt et al. (2012) showing this result for the U.S. dairy and cow-calf industries, respectively. Our research supports these findings, showing that most TMPPS are technically complementary or, at the very least, adopters of one TMPPS are prone to also adopt most others. We used the Fisher exact test (Zar, 1984, p. 390) to determine whether usage among TMPPS was correlated and, in cases where correlation was found, the Cramer coefficient (Zar, 1984, p. 322) to determine whether a complementary or substitute relationship existed among each of the TMPPS. These analyses were conducted using the 2010 ARMS dairy data with the provided weights. Results showed that adoption of all TMPPS was positively correlated with the adoption of all other TMPPS with the exception of: (1) use of a certified organic system was negatively correlated with all other TMPPS except for use of a breeding season and a pasture-based system; (2) use of a pasture-based system was negatively correlated with all other TMPPS except for uses of a breeding season and a certified organic system; (3) use of a breeding season was negatively correlated with veterinary services, use of a nutritionist, forward purchasing of inputs, three-times daily milking, a holding pen with an udder washer, and rbST; (4) use of artificial insemination was negatively correlated with uses of a certified organic system, a pasture-based system, and a parlor; and (5) no relationships were found between artificial insemination and breeding season, parlor and embryo transfer / sexed semen, and rbST and holding pen with an udder washer. Overall, results show striking support for previous findings suggesting that TMPPS adopters tend to be adopters of other TMPPS except for cases of alternative systems such as certified organic and pasture-based production.

\section{Conclusions}

Aggregate adoption rates of most major productivity-enhancing TMPPS have increased over the past couple of decades. Of the computerized and/or automated technologies, automatic take-offs have experienced the highest adoption diffusion rates, moving from $13 \%$ to $40 \%$ aggregate adoption from 1993 to 2010, though diffusion appears to have slowed during 2005-2010. Most of the other technologies in this category have experienced relatively slow adoption diffusion, with all but a computer for record-keeping and internet use for dairy information having aggregate adoption rates less than $10 \%$ throughout the period of study. It is noted, however, that for three of these technologies, percentages of milk produced covered by the technologies greatly exceeds percentages of farms using them, suggesting greater usage among larger farms. This is further supported by logit 
results showing farm size to be positively associated with usage of the six technologies in this category. Furthermore, farms more heavily specialized in milk production and farmers with college degrees were the more likely users of these technologies while certified organic and pasture-based farms were generally the less likely users.

Of the three breeding and/or biological technologies, only artificial insemination held steady during the $2005-2010$ period: $80-82 \%$ of farms used it and $89-91 \%$ of gross value of milk production was covered by the technology. Its aggregate adoption increased relative to 2000. This technology is likely approaching a "ceiling" or equilibrium value, a result that should not be surprising given the rapid early adoption of this technology in the 1940s and its relatively high current usage. Newer technologies, such as embryo transfer / sexed semen and rbST have experienced significant diffusion, with the former increasing both in usage and percentage of production coverage by about $70 \%$ during 2005-2010. This is likely attributed primarily to sexed semen, a relatively new technology that has been expected to experience significant diffusion (DeVries et al., 2008). On the other hand, after initially modest diffusion following its commercial release in 1994, rbST usage decreased from 2005 to 2010, with a 49\% reduction in farms using it. This rather dramatic decrease is likely explained by negative consumer reactions to milk produced using the technology, premiums in some cases being paid for milk not produced using rbST, and small or nonexistent impacts of rbST use on farm profitability (Tauer 2009; Gillespie et al., 2010). For each of the breeding and/or biological technologies, usage was concentrated among larger-scale operations, as indicated by the higher percentages of milk production covered by the technologies relative to percentages of farms using them, and significant Cows or Acres coefficients in the logit models. Certified organic farms were less likely to use any of these technologies (they are barred from using $\mathrm{rbST}$ ), and more highly educated producers were more extensive users of the breeding technologies.

Each of the dairy management practices had relatively steady aggregate adoption rates during 2005-2010; percentages of farms using the practices did not differ significantly for the two years. Figure 3 illustrates a relatively steady aggregate adoption since 2005 . Larger farms were greater users, as indicated by the higher percentages of milk production covered by the management practices relative to percentages of farms adopting, and significant Cows or Acres coefficients in the logit models. Increased percentages of owned land and the farmer holding a college degree increased usage, while older farmers were generally lower users of management practices. Certified organic and pasture-based producers were lower users of the management practices, with the exception of certified organic producers keeping individual cow production records, as expected due to the stringent requirements of USDA certified organic production.

Several trends can be seen in the selection of dairy systems. As farms have increased in size and dairy farming has become more intensive (versus extensive) in nature, higher percentages of farms have adopted parlor systems and are milking cows at least three times a day. In the face of these trends, however, percentages of farms producing under pasture-based systems have remained steady and certified organic dairy production has increased. This suggests that U.S. dairy production is becoming more diverse in its use of production systems, more intensive on the one hand and more likely certified organic and/or pasture-based on the other. Larger, more specialized farms operated by farmers with college degrees were more likely to milk cows at least three times a 
day, and larger farms were more likely to utilize a dairy parlor. Certified organic and pasture-based operations were more likely to control breeding and/or calving seasons.

It is worthwhile to point out the major impact that education had on TMPPS use. College was significant with a positive sign for 11 of the 17 TMPPS for which logit models were estimated. Numbers of percentage points by which usage by college degree-holding farmers exceeded that by non-degree holders ranged from six (computerized milking system) to 33 (accessing the internet for dairy information). College was particularly important for adopting computerized and/or automated technologies and breeding and/or biological technologies, underscoring the importance of training in adopting productivity-enhancing technology.

In order for many extension economists to serve their full dairy clientele, they need to be knowledgeable about the available TMPPS in terms of costs and benefits associated with each one of them. Further research should continue to focus on the advantages and disadvantages of each of these TMPPS systems under different production environments, as well as their associated costs and benefits.

\section{Competing interests}

The authors declare that they have no competing interests.

\section{Authors' contributions}

JG conducted the logic analyses and figures and drafted the manuscript. RN conducted the difference in means analysis and assisted with drafting the manuscript. IS assisted with drafting the manuscript. All authors read and approved the final manuscript.

\section{Acknowledgement}

The views expressed are those of the authors and do not necessarily represent the views or policies of the USDA.

\section{Author details}

${ }^{1}$ Department of Agricultural Economics and Agribusiness, Louisiana State University Agricultural Center, Martin D Woodin Hall, Baton Rouge, LA 70803, USA. Economic Research Service, 1800 M St. NW, Washington, DC 20036, USA. ${ }^{3}$ Department of Agricultural Economics and Agribusiness, Louisiana State University, Martin D Woodin Hall, Baton Rouge, LA 70803, USA.

Received: 12 February 2014 Accepted: 25 September 2014 V.

\section{References}

Amos HE, Kiser T, Lowenstein M (1985) Influence of milking frequency on productive and reproductive efficiencies of dairy cows. J Dairy Sci 68:732-739

Barber KA (1983) Maximizing the impact of dairy and beef bulls through breeding technology. J Dairy Sci 66:2661-2671

Cochrane WW (1958) Farm Prices: Myth and Reality North Central Publishing, St. Paul, MN

DePeters EJ, Smith NE, Acedo-Rico J (1985) Three or two times daily milking of older cows and first lactation cows for the entire lactation. J Dairy Sci 68:123-132

DeVries A, Overton M, Fetrow J, Leslie K, Eicker S, Rogers G (2008) Exploring the impact of sexed semen on the structure of the dairy industry. J Dairy Sci 91:847-856

Dubman, R.W. (2000) Variance estimation with USDA's farm costs and returns surveys and agricultural resource management study surveys. Staff paper AGES 00-01, USDA-ERS; Washington, DC

Erdman RA, Varner M (1995) Fixed yield responses to increased milking frequency. J Dairy Sci 78:1199-1203

Feder G, Just RE, Zilberman D (1985) Adoption of agricultural innovations in developing countries. Econ Dev Cult Change 33:255-298

Foote RH (1996) Review: Dairy cattle reproductive physiology research and management - Past progress and future prospects. J Dairy Sci 79:980-990

Gillespie J, Mark T, Sandretto C, Nehring R (2009a) Computerized technology adoption among farms in the U.S. dairy industry. J Am Soc Farm Managers Rural Apprais 31:201-209

Gillespie J, Nehring R, Hallahan C, Sandretto C (2009b) Pasture-based dairy systems: Who are the producers and are their operations more profitable than conventional dairies? J Agric Resour Econ 34:412-427

Gillespie J, Nehring R, Hallahan C, Sandretto C, Tauer L (2010) Adoption of bovine somatotropin in the United States and its influence on farm profitability, 2000 and 2005. AgBioForum 13(3):251-262

Gisi DD, DePeters EJ, Pelissier CL (1986) Three times daily milking of cows in California dairy herds. J Dairy Sci 69:863

Greene WH (2000) Econometric Analysis. Prentice Hall, New Jersey

Griliches Z (1957) Hybrid corn: an exploration in the economics of technological change. Econometrica 25(4):501-522

Grisham E, Gillespie J (2008) Record-keeping technology adoption among dairy farmers. J Am Soc Farm Managers Rural Apprais 30:16-27 
Horner, J., R. Milhollin, and W. Prewitt (2012) Economics of Pasture-Based Dairies. Publication m192, University of Missouri Extension Service, Columbai, MO

Khanal AR, Gillespie J (2013) Adoption and productivity of breeding technologies: evidence from U.S. dairy farms. AgBioForum 16(1):53-65

Khanal A, Gillespie J, MacDonald J (2010) Adoption of technology, management practices, and production systems in U.S. milk production. J. Dairy Sci 93(12):6012-6022

Mayen C, Balagtas J, Alexander C (2010) Technology adoption and technical efficiency: organic and conventional dairy farms in the United States. Am J Agric Econ 92(1):181-195

McBride W, Greene C (2009) Costs of organic milk production on U.S. dairy farms. Rev Agric Econ 31(4):793-813

McBride W, Short S, El-Osta H (2004) The adoption and impact of bovine somatotropin on U.S. dairy farms. Rev Agric Econ 26:472-488

Mishra A, Perry J (1999) Forward contracting of inputs: A farm-level analysis. J Agribus 17(2):77-91

National Research Council, Panel to Review USDA's Agricultural Resource Management Survey (2008) Understanding American Agriculture: Challenges for the Agricultural Resource Management Survey. National Academy Press, Washington, DC

Pesaran MH, Shin Y, Smith RP (1999) Pooled mean group estimation of dynamic heterogeneous panels. J Am Stat Assoc 94(446):621-634

Pruitt R, Gillespie J, Nehring R, Qushim B (2012) Adoption of technology, management practices, and production systems by U.S. beef cow-calf producers. J Agric Appl Econ 44(2):203-222

Short S (2000) Structure, management, and performance characteristics of U.S. dairy farms. Agricultural Handbook No. 720, USDA - Economic Research Service, September, Washington, DC

Tauer LW (1998) Cost of production for stanchion versus parlor milking in New York. J Dairy Sci 81(2):567-569

Tauer LW (2009) Estimation of treatment effects of recombinant bovine somatotropin using matching samples, Rev Agric Econ 31(3):411-423

Turner L, Skele T (2007) Dairy herd batch calving: Findings from the sustainable dairy farm systems for profit project. M5 Info Series - 133 Batch Calving, Department of Primary Industries and Fisheries, Queensland, Australia

Ward CE, Vestal MK, Doye DG, Lalman DL (2008) Factors affecting adoption of cow- calf production practices in Oklahoma. J Agric Appl Econ 40(3):851-63

Wiegel KA (2004) "Exploring the role of sexed semen in dairy production systems. J Dairy Sci 87(E-Suppl):E120-E130

Zar JH (1984) Biostatistical Analysis, 2nd edn. Prentice-Hall, Englewood Cliffs, NJ

doi:10.1186/s40100-014-0017-y

Cite this article as: Gillespie et al:: The adoption of technologies, management practices, and production systems in U.S. milk production. Agricultural and Food Economics 2014 2:17.

Submit your manuscript to a SpringerOpen ${ }^{\circ}$ journal and benefit from:

- Convenient online submission

- Rigorous peer review

- Immediate publication on acceptance

- Open access: articles freely available online

- High visibility within the field

- Retaining the copyright to your article

Submit your next manuscript at $>$ springeropen.com 